$\overline{1-ト}$

\title{
化学発光法を用いた細胞毒性試験法の検討
}

(平成 9 年 5 月 2 日受理)

北 村 和子* 諏訪 芳 秀*

\section{Application of Chemiluminescent Assay in Cytotoxicity Tests}

\author{
Kazuko Kitamura and Yoshihide Suwa
}

(Institute for Fundamental Research, Suntory Co., Ltd.: 1-1-1, Wakayamadai, Shimamoto-cho, Mishima-gun, Osaka 618, Japan)

This study showed that chemiluminescent $(\mathrm{CL})$ assay is superior to Giemsa staining assay or MTT reduction assay in sensitivity and rapidity for detection of the cytotoxic effects of four compounds (phenobarbital sodium, theophyllin, propranolol and thioridazine). Furthermore, HepG2 cells were found to be more suitable for CL assay than intestine 407 cells, being more susceptible to the toxicity of the four compounds.

(Received May 2, 1997)

Key words: 細胞毒性試験 cytotoxicity test; 化学発光法 chemiluminescent assay; ヒト小腸上 皮細胞 intestine 407; ヒト肝ガン細胞 HepG2

\section{緒言}

動物実験代替法のひとつとして，ヒト細胞を含めた各 種動物細胞を用いた細胞毒性試験がある.

細胞毒性を測定する方法としては大別して 2 タイプ がある.まず,ひとつのタイプは被験物質処理後の生細 胞数を測定して細胞毒性を推定するギムザ染色法, MTT 還元法 ${ }^{1)}$ 及びニュートラルレッド (NR) 法") に代表 される方法である.これに対して被験物質処理後の細胞 死を測定する LDH 法 ${ }^{3) \sim 5)}$ に代表される方法む広く用い られている.

山庄司らが考案した, 化学発光法を導入した細胞毒性 試験 ${ }^{6) ~ 9) ~}$ は前者の方法に属する. すなわち, 本法は生細 胞のみが細胞内に取り込んだメナジオン（ビタミン $\mathrm{K}_{3}$ ) を代謝し, NAD(P)H に依存して過酸化水素を生成 することに着目し，生成した過酸化水素がビス $[2-$ (3,6,9-トリオキサデカニルオキシカルボニル)-4-ニトロ フェニル]オキザレート (TDPO) とピレンによる蛍光反 応を触媒・六進することを応用したものである。この方 法は他の試験法と比較して, 簡便でしかも短時間で毒性 を検出することが期待できる方法である. しかしなが

* サントリー(株)基礎研究所： $\mathbf{7} 618$ 大阪府三島郡島本町若 山台 1-1-1
ら，本法は現在開発途上にあり，以下の懸案事項の克服 が待たれるところである.

それらは(1) 本法に適した細胞種及び被験物質処理時 間の選定，(2) 非特異的な化学発光の排除，(3) 代謝活性 化法の導入，そして (4) 多くの有毒物質に関する本法に よる毒性データの蓄積である.

著者らはこれらの事項のうち (1)について検討するた め MEIC (Multicentre Evaluation of in vitro Cytotoxicity, organized by the Scandinavian Society of Cell Toxicology $)^{10)}$ に記載されている物質の中から 4 化合物 [フェノバルビタールナトリウム (CAS 番号 57-30-7), テオフィリン (58-55-9), プロプラノロール (3506-090)，チオリダジン (130-61-0)] を選び，それらを用いて 化学発光法による細胞毒性試験の優位性について, ギム ザ染色法及び MTT 還元法と比較検討した。これらの化 合物を選択するに際しては, 食品あるいは食品素材の安 全性評価を想定して強い毒性を示す物質はあえて除外し た. 4 種の化合物はいずれあ医薬品としてあ使用され, いわゆる毒物ではない，食品の毒性を検出する目的から は比較的毒性の低い物質であ検出できる手法が望まし い. また，テオフィリンは茶類などの嗜好品にあ含まれ る食品成分であある.フェノバルビタールナトリウム は, 薬物代謝酵素を誘導する薬物であり今後, 代謝活性 
化法を導入するに当たり必要であると判断した．また， 食品あるいは食品素材の安全性評価には, 消化器官由来 の細胞で毒性の検出感度が高い細胞を用いることも重要 と考え，小腸上皮細胞 (intestine 407) あるいは肝細胞 (HepG2) を用いて, 毒性検出感度を比較した.

\section{実 験 方 法}

\section{1. 供試細胞及び培養方法}

HepG2 (Human hepatocellular carcinoma, ヒト肝 ガン細胞 ATCC HB8065) は 10\% 牛胎児血清 (FBS), $4 \mathrm{mmol} / \mathrm{L}$ L-グルタ ミン及び $1 \%$ ペニシリン $\mathrm{G}$ を含む Dulbecco's modified Eagle's minimum essential medium (D-MEM) を用いて, また, intestine 407 (七 卜胎児小腸上皮細胞 ATCC CCL6）は 10\%FBS 及び 4

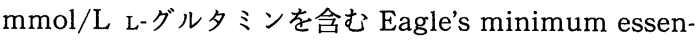
tial medium (E-MEM) を用いて培養した. いずれの細 胞む， $37^{\circ} \mathrm{C}$ における $5 \% \mathrm{CO}_{2}$ 飽和蒸気圧下で培養し， 実験に供した。

\section{2. 供試試薬}

TDPO, ドデシル硫酸ナトリウム (SDS), フェノバル ビタールナトリウムは和光純薬工業(株)製を, テオフィ リン, メナジオン (ビタミン $\left.\mathrm{K}_{3}\right)$ ，ピレンはナカライテ スク(株)製を，プロプラノロール，チオリダジンは Sigma 社製を用いた. TDPO，ピレンの溶解には高速 液体クロマトグラフ用アセトニトリルを，メナジオンは 特級エタノール [いずれあ和光純薬工業(株)］を用いて 溶解し, 他の試薬は蒸留水 (NANO pure; Barnstead) にて溶解した.

\section{3. ギムザ染色法}

細胞を培地中に懸濁させ, 96 穴マイクロプレート (Nunc) に分注 $\left(10^{3}\right.$ cells $/ 100 \mu \mathrm{L} /$ well) した後，48時 間培養した。培養後, 培地を除去し PBS で洗浄後, 新 しい培地を $100 \mu \mathrm{L}$ ずつ分注し, 被験物質（フェノバル ビタールナトリウム； $0,5,10,20,30 \mathrm{mmol} / \mathrm{L}$, テオ

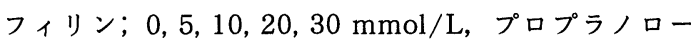
ル; $0,200,300,400,500 \mu \mathrm{mol} / \mathrm{L}$ ，チオリダジン; 0 , $10,20,40,50 \mu \mathrm{mol} / \mathrm{L})$ を $10 \mu \mathrm{L}$ ずっ添加した. 3 時 間の処理後, 被験物質を除去し, 新しい培地で洗浄後, 培地を新たに $100 \mu \mathrm{L}$ ずつ分注し，更に 48 時間培養し た. 培養後, 培地を除去し, PBS で洗浄後, メ夕ノ一 ルで 20〜30 分間固定した. 次に, 30〜60 分乾燥させ, $4 \%$ ギムザ染色液で 30 分間染色した．染色液を除去 し, 2〜3 時間風乾させ, マイクロプレートリーダー (EL $312 \mathrm{e}$ 型; BIO-TEK Instruments) を用いて 540 $\mathrm{nm}$ にて吸光度を測定した. 測定值より細胞の相対的生 存率を求め, $\mathrm{IC}_{50}$ 值を算出した. 実験は 2 回実施し, 処理濃度当たりの被験物質数は 3 サンプルとした。

\section{MTT 還元法}

96 穴マイクロプレート (Nunc) に細胞懸濁液 $\left(6 \times 10^{3}\right.$ cells $/ 100 \mu \mathrm{L} /$ well) を播種し，培地で処理濃度に調製し

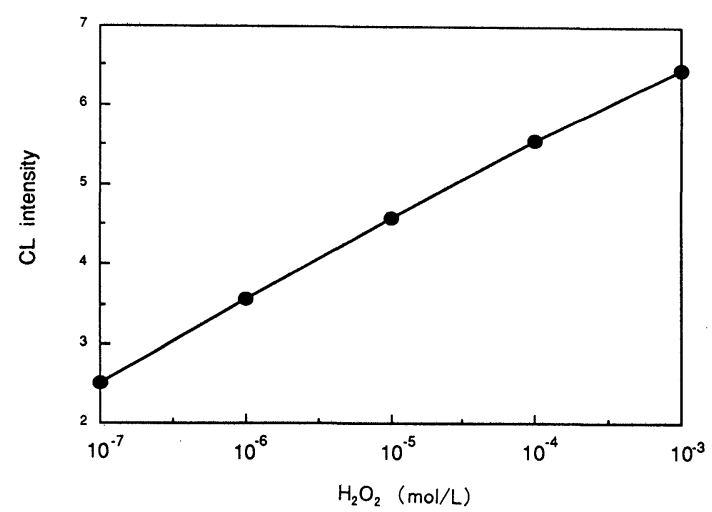

Fig. 1. Plot of chemiluminescence (CL) intensity vs. logarithm of $\mathrm{H}_{2} \mathrm{O}_{2}$ concentration

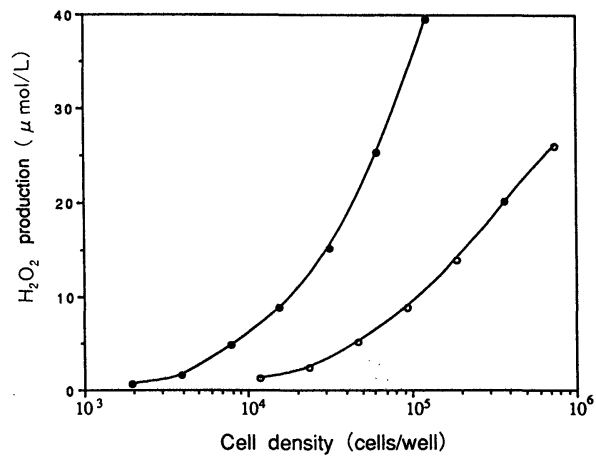

Fig. 2. Plot of cell density $v s$. menadion-catalyzed $\mathrm{H}_{2} \mathrm{O}_{2}$ production

Trypsinized cells were diluted with medium to obtain samples of various numbers of cells per well of a 96-well tissue culture plate. Samples of $100 \mu \mathrm{L}$ of cell were introduced into each well. Chemiluminescent assay of $\mathrm{H}_{2} \mathrm{O}_{2}$ production was performed as described in Materials and Methods.

Closed symbols: $\mathrm{H}_{2} \mathrm{O}_{2}$ generated from HepG2; Open symbols: $\mathrm{H}_{2} \mathrm{O}_{2}$ from intestine 407 .

た被験物質（ギムザ染色法と同じ種類と処理濃度）を $100 \mu \mathrm{L}$ 添加した. 48 時間培養後, MTT の $4 \mathrm{mg} / \mathrm{mL}$ $\mathrm{PBS}$ 溶液を $20 \mu \mathrm{L}$ ずっ各ウエルに分注し $37^{\circ} \mathrm{C}$ で 4 時 間処理した. 次に $1,800 \sim 2,000 \mathrm{rpm}$ で 5 分間遠心分離 し上清を除去した．各ウエルに $0.04 \mathrm{~mol} / \mathrm{L}$ 塩酸一イソ プロピルアルコール溶液を $150 \mu \mathrm{L}$ ずつ分注し, マイク ロプレート用ミキサー (MPM-1; Iwaki) で生成したフォ ルマザンを $5 \sim 10$ 分間抽出した. マイクロプレート

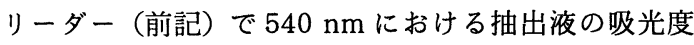
を測定した。 測定值より細胞の相対的生存率を求め $\mathrm{IC}_{50}$ 值を算出した．実験は 2 回実施し，処理濃度当たりの 

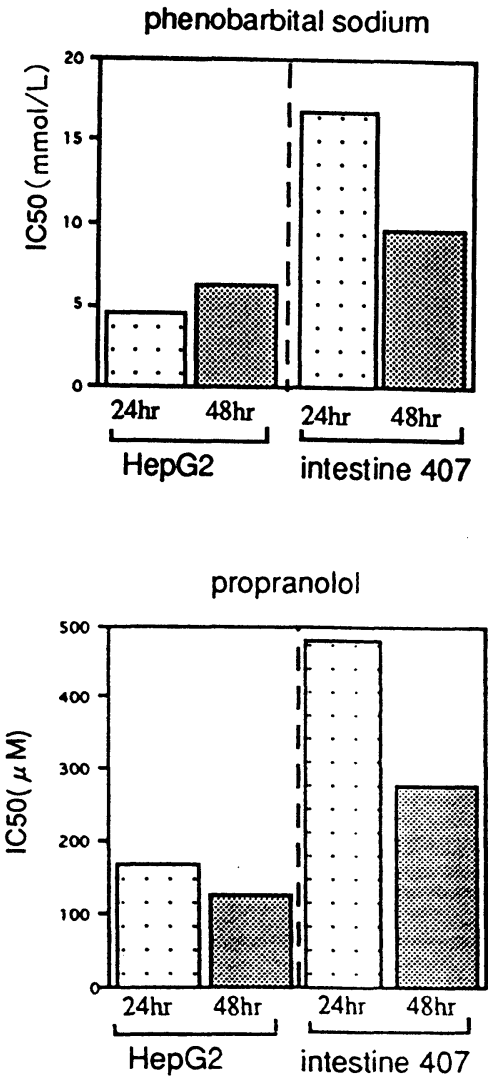
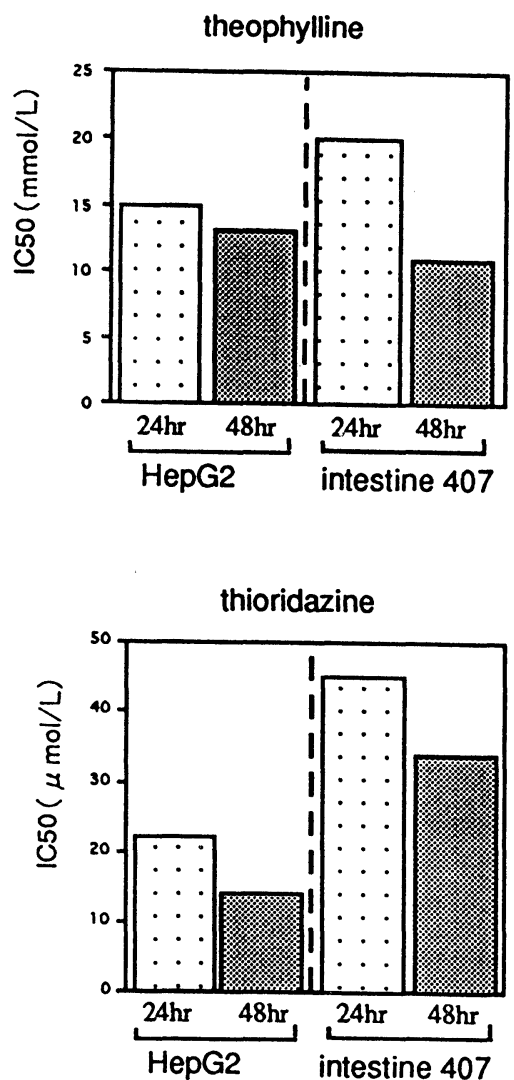

Fig. 3. Influence of treatment-time on the appearance of cytotoxicity

Bars show the mean $\mathrm{IC}_{50}$ values in three separate experiments. Trypsinized cells were diluted with medium and introduced into 96 -well tissue culture plates at 50,000 cells/well $(24 \mathrm{hr})$ or 10,000 cells/well $(48 \mathrm{hr})$.

The cells were incubated with test compounds for $24 \mathrm{hr}$ or $48 \mathrm{hr}$. Then the cells were washed with medium and fresh medium was added. Viability was determined by CL assay.

被験物質数は 3 サンプルとした.

\section{5. 化学発光法}

96 穴マイクロプレート (Nunc) に細胞懸濁液 (3 時間 処理は $6 \times 10^{3}$ cells, 24 時間処理は $5 \times 10^{4}$ cells, 48 時 間処理は $10^{4}$ cells $/ 100 \mu \mathrm{L} /$ well) を播種し, 被験物質 （ギムザ染色法と同じ種類と処理濃度）を $10 \mu \mathrm{L}$ ずつ添 加した. 各々の処理時間後に被験物質を除去し, 新しい 培地を $100 \mu \mathrm{L}$ ずつ分注し, 更に 48 時間培養した. 培 養後, フェノールレッドとグルタミンを含有しない MEM 培地 (Sigma M4144) で洗浄後, 更に新しい培地 を $100 \mu \mathrm{L}$ ずつ分注した。 ルミネセンサー (AB-2000; ATTO) を用いてメナジオンを用いた化学発光法により 細胞の過酸化水素生成量を測定した．測定値より細胞の 相対的生存率を求め $\mathrm{IC}_{50}$ 值を算出した。化学発光法に

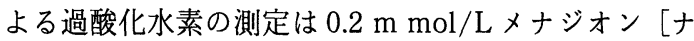
カライテスク(株)］のエタノール溶液 $2 \mu \mathrm{L}$ を測定用培
地 $50 \mu \mathrm{L}$ ととあに 5 分間 $37^{\circ} \mathrm{C}$ でインキュベートした 後に, TDPO とピレンの高速液体クロマトグラフィー 用アセトニトリル混合溶液 $100 \mu \mathrm{L}$ を各ウェルに分注し た. その直後の 10 秒間の発光量を測定し，そのうちの 最初の 5 秒間の発光量を積算した。なお, 試薬はすべ て自動的に分注した。実験は 2 回実施し, 処理濃度当 たりの被験物質数は 3 サンプルとした.

\section{実 験 結 果}

\section{1. 過酸化水素濃度と化学発光量の関係}

過酸化水素濃度と化学発光量の関係を Fig. 1 に示し た。試薬により調製した過酸化水素濃度 $\left(10^{-7} \sim 10^{-3}\right.$ $\mathrm{mol} / \mathrm{L})$ と化学発光量の間には良好な直線性が得られ た. 次に, 試験に用いる 2 種の細胞 (intestine 407 及 び HepG2) からメナジオン添加によって生成する過酸 化水素量を測定した (Fig. 2). その結果, intestine 407 に比べ HepG2 のほうが過酸化水素生成量が 3 4 倍程 

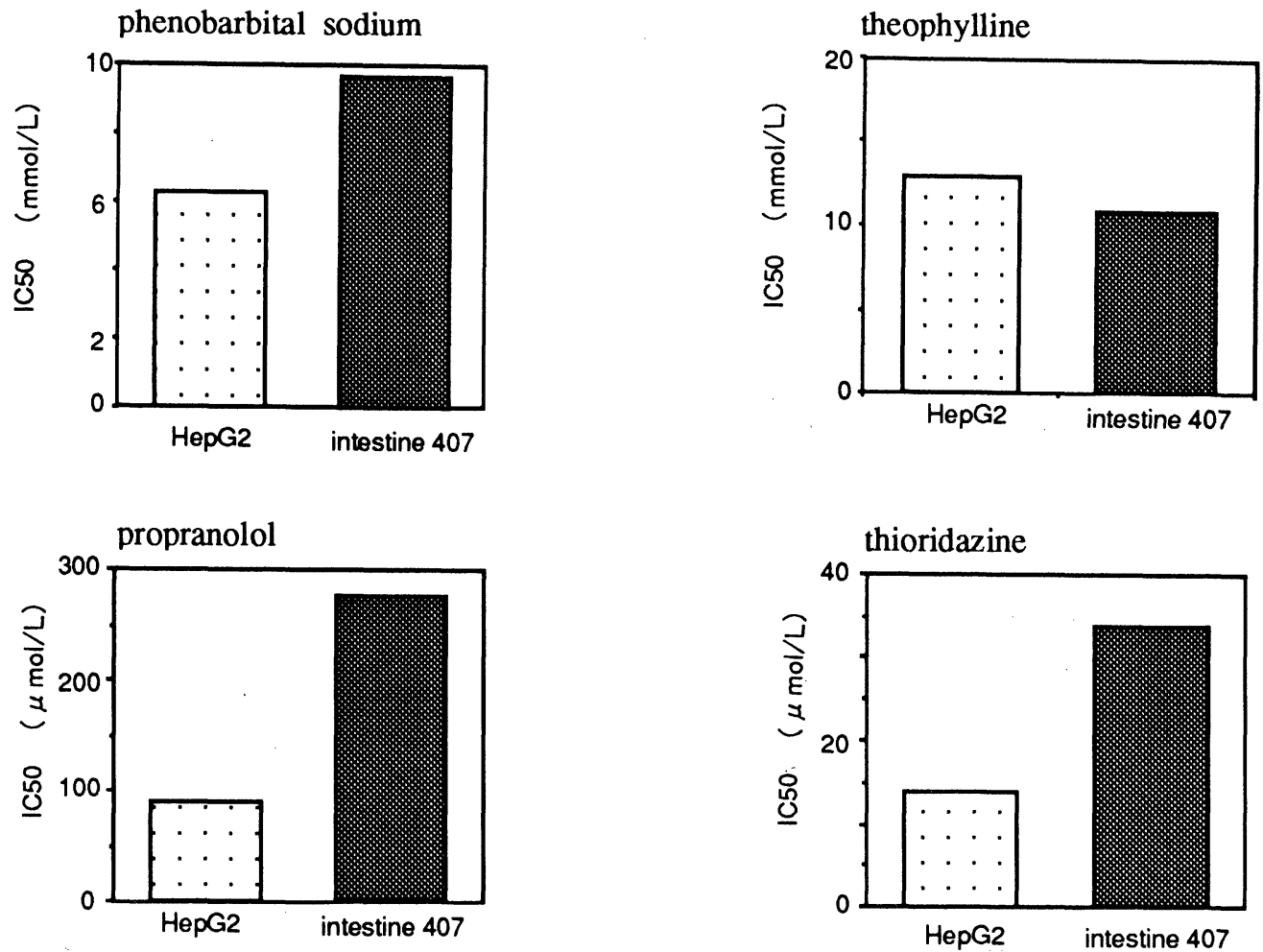

Fig. 4. Comparison of susceptibilities of HepG2 cells and intestine 407 cells in the CL assay

Bars represent mean $\mathrm{IC}_{50}$ values for three separate experiments.

Trypsinized cells were diluted with medium and introduced at 10,000 cells/well into 96-well tissue culture plates. The cells were incubated with each chemical for 3 $\mathrm{hr}$. Then they were washed and incubated in fresh medium for $48 \mathrm{hr}$. Viability was determined by CL assay.

度多いことが分かった．また，測定に最適な発光量を得 るためには細胞種により試験に供する細胞数を変える必 要があることが分かった。（過酸化水素を約 $10 \mu \mathrm{mol} / \mathrm{L}$ 生成するに十分な細胞数を基準とし, intestine 407 に ついては $10^{5}$ cells $/ 100 \mu \mathrm{L} /$ well, HepG 2 は $10^{4}$ cells / $100 \mu \mathrm{L} /$ well と設定した. )

\section{2. 被験物質処理濃度及び時間による毒性評価}

MEIC 記載の 4 種の化合物の intestine 407 及び HepG2 の両細胞に対する細胞毒性を化学発光法で評価 したところ，いずれの被験物質にも濃度依存的な生物活 性 (viability) 低下作用を認めた（図示せず). 被験物質 処理時間（24 時間あるいは 48 時間）の違いによる intestine 407 及び HepG2 における毒性発現の較差を示 す (Fig. 3). 2 種の細胞を用いて二つの処理時間によっ てもたらされた 4 種の化合物の $\mathrm{IC}_{50}$ 值の中での最低値 は, フェノバルビタールナトリウムでは $4.63 \mathrm{mmol} / \mathrm{L}$ (HepG 2 に対する 24 時間処理), テオフィリンでは $10.85 \mathrm{mmol} / \mathrm{L}$ (intestine 407 に対する 48 時間処理),
プロプラノロールでは $113.56 \mathrm{mmol} / \mathrm{L}$ (HepG2 に対す る 48 時間処理) 及びチオリダジン $13.55 \mathrm{mmol} / \mathrm{L}$ （HepG2 に対する 48 時間処理）であった. フェノバル ビタールナトリウムの $\mathrm{HepG} 2$ に対する $\mathrm{IC}_{50}$ 值が 24 時 間処理の場合に 48 時間処理に比べ $26 \%$ ほど低值を示 したことを除いては，4種の化合物とも 48 時間処理の 方が毒性が強く認められた $\left[\mathrm{IC}_{50}(24 \mathrm{hr} / 48 \mathrm{hr})\right.$ 比で $1.16 \sim 3.02]$.

また, いずれの化合物であ intestine 407 に対しては 48 時間処理の場合に細胞毒性は強く発現した (Fig. 3).

\section{3. 細胞種による検出感度の比較}

次に処理時間を 3 時間に限定した場合の両細胞種の 4 種の化合物に対する感受性を比較した (Fig. 4). Intestine 407 に比べ HepG2 の方が, 毒性の検出感度が概し て高い傾向が認められた. したがって, 当初 intestine 407 が消化管由来の細胞であり消化管に対する毒性の検 出には適していると考えられたものの, 感度の点では HepG2 のほうが優っていることが明らかになった。 

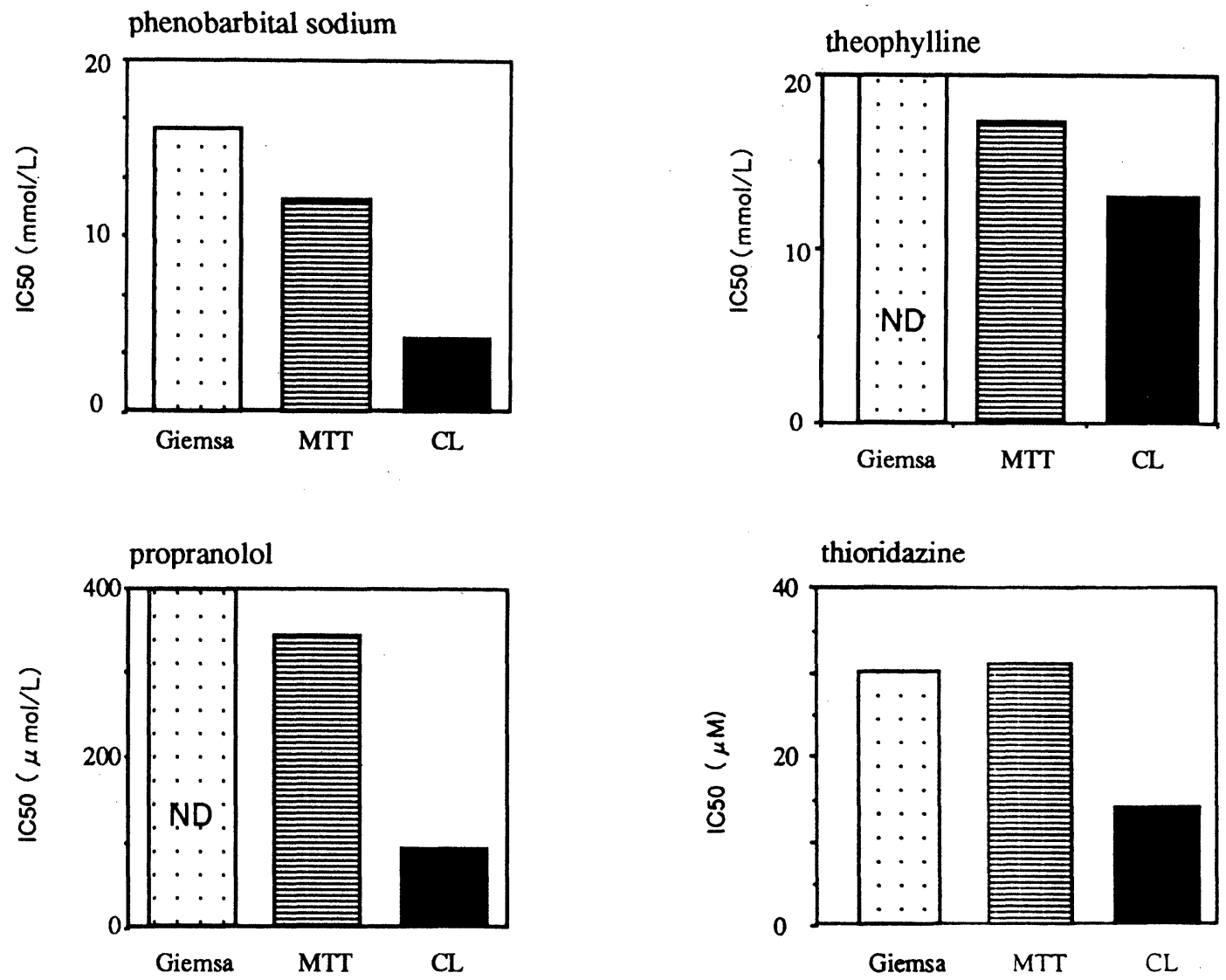

Fig. 5. Comparison of susceptibilities of HepG2 cells determined by Giemsa staining assay,

MTT reduction assay and CL assay

Bars represent mean $\mathrm{IC}_{50}$ values in 3 separate experiments.

The procedures for the three assays are described in Materials and Methods.

ND: not detected

\section{4. 細胞毒性試験法の比較}

HepG2 を用いて, ギムザ染色法, MTT 還元法及び 化学発光法による細胞毒性試験法から得られた $\mathrm{IC}_{50}$ 值 を Fig. 5 に示した. それぞれの被験物質処理時間は, ギムザ染色法及び化学発光法では 3 時間, MTT 還元法 では 48 時間である. 4 種の化合物の $\mathrm{IC}_{50}$ 值は化学発光 法を用いて求められた值が, 他の 2 法を採用した場合 に比べ 25〜 75\% 低いことが判明した. したがって，い ずれの化合物においても化学発光法のほうが高感度に毒 性を検出できることが分かった.

\section{考察}

毒物には濃度に応じて即時的に毒性を示すむのと, 慢 性的あるいは蓄積されて毒性を示すあのがある. 毒物が 安定であれば, 処理時間とともに毒性が強く現れること は当然考えられるが, 細胞に対する処理時間の長期化に よって毒性を発現する傾向の強い物質は, 細胞への取り 込みや代謝活性化に時間を要するあのああると思われ
る. 濃度に応じて毒性を示す物質は種々の細胞毒性試験 法で検出可能であるが, 慢性的あるいは蓄積されて毒性 を示すあのは困難である. 今回の実験を通じ, 化学発光 法と 2 種の試験法を比較検討した結果, 化学発光法は 接着, 浮遊細胞のいずれをあ用いることができ, また, 測定時間が数分で終了するため, 被験物質処理時間の細 かい設定が可能であった. 他方, ギムザ染色法は接着細 胞のみ, また, MTT 還元法は接着, 浮遊細胞のいずれ に対しても用いることができるが, 共に指標色素の取り 込みに時間を要し, 測定までの間の細胞の生物活性の変 化を見ることができない. したがって，化学発光法の優 位性としては濃度に応じて毒性を示す物質と慢性的ある いは蓄積されて毒性を示す物質の両者を対象として, ま ず分単位での毒性発現パターンを検討することが可能で ある点を挙げられる. 化学発光法は, 遅発性, 即発性の 両方の毒性を把握できる優れた方法であると言えよう.

更に, 化学発光法は他の試験法に比べ試験期間も短く 
（化学発光法：1〜3日, MTT 法： 3 日，ギムザ法：5 日）多種の被験物質を 1 度に処理することができるた め，迅速な対応が可能な試験法であると言える.

本報では細胞種によって検出感度が異なることを示し た.すなわち, intestine 407 に比べ HepG2 の方が毒 性の検出感度が概して高い傾向が認められた。 ちなみ に, 山庄司 ${ }^{9)}$ により, PC-3, NIH/3T3, HuH-6KK 及 び CLL64 の各細胞種の生成過酸化水素量が示されてい る.これによると各細胞種を用いた場合の過酸化水素生 成量は, 今回の実験における intestine 407 之同程度で あり, HepG2 採用時よりあ低いものと見なされる. 化 学発光法による細胞毒性試験では, まず HepG2 の採用 を考えるべきと思われる.

\section{結論}

メナジオンの還元的代謝を利用した化学発光法による 細胞毒性試験を検討した結果，以下の結論を得た。

1. 本法は分単位での毒性発現パターンを解析するこ とが可能である.

2. 本法の毒性検出感度はギムザ染色法や MTT 還元 法よりも 3〜4 倍程度優れていた.

3. 本法に用いる細胞としては，ヒト胎児小腸上皮細 胞 (intestine 407) よりあヒト肝ガン細胞 (HepG2) のほ うが感度の点で優れていた。
謝辞

化学発光法の導入と検討にあたり, 貴重なご助言をい ただきました神戸学院女子短大, 山庄司志朗教授に深謝 申し上げます。

文献

1) Mosmann, N.: J. Immun. Meth. 65, 55 63 (1983).

2) Borenfreud, E., Puerner, J .A.: Toxicol. Lett. 24(1), 19 $\sim 23$ (1985)

3) Korenzeniewski, C., Callewart, D. M.: J. Immunol, Methods $64,313 \sim 318$ (1983).

4) Szekers, J., Pacsa, A. S., Pejtsik, B.: ibid. 40, 151 157 (1981).

5) Sasaki, T., Kawai, K., Ohno, T.: Toxicol. in Vitro 6(5), 451 457 (1992).

6) Yamashoji, S., Ikeda, T., Yamashoji, K.: Anal. Biochem. 181, 149 152 (1989).

7) Yamashoji, S., Ikeda, T., Yamashoji, K.: Biochem. Biophys. Acta 1,059, 99 105 (1991).

8) Yamashoji, S., Ikeda, T., Yamashoji, K.: Anal. Biochem. 207, 255 260 (1992).

9) 山庄司志朗, 西本普喜子：組織培養 20(4), 155 159 (1994).

10) Ponsoda, X., Jover, R.: Toxicol. in Vitro 9(6), 959 966 (1995). 